\title{
Penggunaan Model Cooperative Learning Tipe Picture and Picture sebagai Upaya Meningkatkan Kreativitas dan Hasil Belajar Muatan IPA Peserta Didik di Kelas IV SDN 98/X Rantau Indah Semester Ganjil Tahun Ajaran 2021/2022
}

\author{
Rosita \\ SDN 98/X Rantau Indah \\ Jl.kh.dewantara No.12, Rantau Indah, Kec. Dendang, Kab. Tanjung Jabung Timur, Jambi. \\ rosita@gmail.com
}

\begin{abstract}
This study aims to describe and obtain information on increasing creativity and learning outcomes for science content through the Picture and Picture Cooperative Learning Model. This research is a classroom action research consisting of two cycles, each cycle consisting of two meetings. Each meeting consists of four stages, namely planning, implementation, observation and reflection. The subjects of this study were fourth grade students of SDN 98/X Rantau Indah, totaling 14 people. This research was conducted in the odd semester of the 2021/2022 academic year. Data collection techniques using tests, observations, and documentation. Data were analyzed using percentages. The results showed that through the Picture and Picture Cooperative Learning Model, it could improve the learning outcomes of the fourth grade students of SDN 98/X Rantau Indah science content learning outcomes.
\end{abstract}

Keywords: Science learning outcomes, Picture and Picture

\begin{abstract}
Abstrak
Penelitian ini bertujuan untuk mendeskripsikan dan mendapatkan informasi peningkatan kreativitas dan hasil belajar muatan IPA melalui Model Cooperative Learning Tipe Picture and Picture. Penelitian ini merupakan penelitian tindakan kelas yang terdiri dari dua siklus masing-masing siklus terdiri dari dua kali pertemuan. Masing-masing petemuan terdiri dari empat tahapan yaitu perencanaan, pelaksanaan, observasi dan refleksi. Subjek penelitian ini adalah peserta didik kelas IV SDN 98/X Rantau Indah yang berjumlah 14 orang. Penelitian ini dilaksanakan pada semeseter ganjil tahun ajaran 2021/2022. Teknik pengumpulan data menggunakan tes, observasi, dan dokumentasi. Data dianalisis menggunakan persentase. Hasil penelitian menunjukkan bahwa melalui Model Cooperative Learning Tipe Picture and Picture dapat meningkatkan hasil belajar muatan IPA peserta didik kelas IV SDN 98/X Rantau Indah.
\end{abstract}

Kata kunci: Hasil belajar IPA, Picture and Picture.

Copyright (c) 2022 Rosita

Corresponding author: Rosita

Email Address:rosita@gmail.com (Jl. Jl.kh.dewantara No.12, Rantau Indah, Jambi)

Received 10 January 2022, Accepted 20 January 2022, Published 17 February 2022

\section{PENDAHULUAN}

Pada dasarnya pendidikan merupakan suatu kegiatan yang bertujuan untuk membentuk peserta didik sehingga memiliki wawasan yang luas serta berdaya guna bagi masyarakat. Pendidikan juga pada hakikatnya harus diterapkan sejak dini tak terkecuali tingkat sekolah dasar (SD). Pendidikan di SD dimaksudkan untuk memberikan bekal kemampuan dasar kepada peserta didik berupa pengetahuan, keterampilan dan sikap yang bermanfaat bagi diri sendiri sesuai dengan tingkat perkembangannya, serta persiapan untuk melanjutkan pendidikan ke jenjang yang lebih tinggi. 
Penggunaan Model Cooperative Learning Tipe Picture and Picture sebagai Upaya Meningkatkan Kreativitas dan Hasil Belajar Muatan IPA Peserta Didik di Kelas IV SDN 98/X Rantau Indah Semester Ganjil Tahun Ajaran 2021/2022, Rosita

Berbagai macam mata pelajaran telah diberikan pada peserta didik pada sekolah dasar salah satunya adalah mata pelajaran IPA.

Pada mata pelajaran IPA ini peserta didik dituntut untuk lebih aktif belajar dalam proses pembelajaran IPA, karena pada pembelajaran IPA peserta didik akan memahami materi yang berupa hukum dan dihubungkannya dengan keadaan alam yang ada di lingkungan. Seperti yang dijelaskan oleh DAPDIKNAS (2006;484) dalam kurikulum satuan tingkat pendidikan IPA yaitu Ilmu pengetahuan alam berhubungan dengan cara mencari tahu tentang alam. Secara sistematis, sehingga Ilmu Pengetahuan Alam bukan hanya penguasaan kumpulan pegetahuan yang berupa teori-teori, fakta-fakta, konsep-konsep, atau prinsip-prinsip saja tetapi juga merupakan suatu proses penemuan. Pendidikan IPA diharapkan dapat menjadi wahana bagi peserta didik untuk mempelajari diri sendiri dan alam sekitar serta prospek pengembangan lebih lanjut di dalam menerapkannya dalam kehidupan sehari-hari'.

Dari uraian di atas diharapkan peserta didik memiliki pemahaman yang luas dan mendalam pada bidang ilmu IPA. Pemahaman peserta didik tentang pembelajaran dibuktikan dengan hasil belajar yang diperoleh peserta didik. Dimyati (2013) menjelaskan bahwa hasil belajar adalah hasil dari suatu interaksi tindak belajar dan tindak mengajar. Dari sisi guru tindak mengajar diakhiri dengan proses evaluasi akhir mengajar. Dari peserta didik hasil belajar adalah berakhirnya panggal dan puncak proses belajar.

Pembelajaran IPA merupakan pembelajaran yang berkaitan dengan hukum dan digabungkan dengan alam. Peserta didik terkadang merasa sangat sulit dalam memahami IPA dikarenakan materi yang begitu kompleks. Untuk itu diperlukan model pembelajaran yang baik ketika proses pembelajaran IPA berlangsung. Model pembelajaran ini merupakan suatu kegiatan pembelajaran yang dirancang atau dikembangkan dengan menggunakan pola pembelajaran tertentu. Pola pembelajaran yang dimaksud dapat menggambarkan kegiatan guru dan peserta didik dalam mewujudkan kondisi belajar atau sistem lingkungan yang menyebabkan terjadinya proses belajar. Dengan model pembelajaran peserta didik akan lebih mudah dalam memahami materi. sehingga diperlukan model pembelajaran yang cocok dalam membahas fenomena fenomena yang ada dalam pembelajaran IPA.

Fenomena yang sering ditemui dalam pelajaran IPA sebetulnya membahas tentang alam. Pembelajaran tentang alam memerlukan tingkatan analisis yang tinggi, maka pada umumnya anak lebih menyukai pelajaran yang berkaitan tentang sosial, penjaskes dan pelajaran yang materinya lebih sederhana. Untuk itu diperlukan model pembelajaran yang baik dalam mata pelajaran IPA. Selain itu anak lebih cepat memahami pembelajaran yang diselingi dengan gambar. Gambar yang dimaksud harus memiliki informasi yang tersirat (fungsi kompensentoris) karena hal ini akan membantu peserta didik yang lemah dalam membaca untuk mengorganisasikan informasi dalam teks dan mengingatnya kembali dengan kata-kata yang lain. Masalah ini bisa dipecahkan dengan mengguakan model pembelajaran Picture and picture. Picture and picture adalah Model pembelajaran picture and picture 
ini merupakan sebuah model pembelajaran dimana guru menggunakan alat bantu seperti media gambar untuk menerangkan sebuah materi atau memfasilitasi peserta didik untuk aktif belajar. Dengan menggunakan alat bantu media gambar tersebut diharapkan peserta didik dapat mengikuti pelajaran dengan fokus yang baik dan dalam kondisi yang menyenangkan, sehingga apapun pesan yang disampaikan oleh guru, bisa diterima dengan baik dan mampu meresap dalam hati, serta dapat diingat kembali oleh peserta didik.

IPA merupakan salah satu mata pelajaran yang wajib diikuti oleh peserta didik karena tujuan dari pembelajaran IPA adalah Untuk mengembangkan rasa ingin tahu dan suatu sikap postif terhadap sains, teknologi dan masyarakat. Rasa ingin tahu akan timbul saat diberikan kata kunci kepada anak, Saat anak memiliki rasa ingin tahu yang tinggi ia mulai mengembangkan keterampilan proses untuk menyelidiki alam sekitar, hal ini terjadi karena adanya rasa ingin tahu. Setelah itu anak mulai mencocokan wawasanya dengan pengetahuan yang ada di IPA Untuk mengembangkan pengetahuan dan pemahaman konsep konsep sains yang akan bermanfaat dapat diterapkan dalam kehidupan sehari hari. Dari situlah anak mulai mengenal alam dan memelihara alam karena konsep ilmiah telah tertanam dari diri anak. Jadi tujuan dari pembelajaran IPA adalah menyuruh anak untuk mencari informasi agar dengan infromasi itu ia dapat implikasikan dalam kehidupan sehari hari.

Manfaat dan tujuan pelajaran IPA sangat banyak, namun kebanyakan peserta didik kurang dalam memahami pembelajaran IPA, untuk itu terdapat beberapa upaya yang dilakukan dalam meningkatkan hasil belajar anak yaitu menjual LKS, menyediakan media pembelajaran dan mengubah susasan dikelas. Menjual LKS dapat membantu peserta didik dalam proses belajar, jika peserta didik diharuskan membeli buku cetak, hal ini akan memberatkan bagi peserta didik, karena tidak semua anak mampu untuk membelinya. Untuk itu diperlukan penjualan LKS sebagai ganti buku cetak. LKS mengandung materi yang lengkap dan juga dilengkapi dengan latihan yang dapat membantu mengasah kemampuan anak dalam belajar. LKS juga memiliki harga yang relatif murah sehingga anak semua anak mampu membelinya.

Pembelajaran IPA merupakan pelajaran yang memerlukan konsetrasi yang tinggi bagi anak sehingga dalam pembelajarannya diperlukan alat bantu berupa media. Media pembelajaran akan membantu guru dalam menjelaskan apalagi jika pelajaran itu berupa sebuah konsep yang berasal dari alam. Konsep dari alam ini harus diperlihatkan berupa contoh dan gambarannya agar anak lebih mudah memahami dan mengerti.

Sebagai pelajaran kompleks guru memerlukan kosentrasi penuh guru dalam memegang beban studi IPA baik itu kemampuan emosional maupun pedogogik. Dalam proses pembelajaran sebaiknya guru berusaha menciptakan suasana kelas seperti rumah. Jika anak berada merasakan suasana kelas seperti suasana dirumah maka anak tidak akan merasa cepat bosan, karena suasana dirumah akan membuat anak nyaman dan dipenuhi kebahagian, yang akan membantu anak dalam proses belajar. Maka permasalahan yang dapat diambil adalah rendahnya hasil belajar IPA di kelas IV SDN 98/X Rantau Indah yang ditandai dengan nilai rata rata UH peserta didik masih banyak dibawah KKM serta 
Penggunaan Model Cooperative Learning Tipe Picture and Picture sebagai Upaya Meningkatkan Kreativitas dan Hasil Belajar Muatan IPA Peserta Didik di Kelas IV SDN 98/X Rantau Indah Semester Ganjil Tahun Ajaran 2021/2022, Rosita

rendahnya minat belajar anak dalam mempelajari IPA. Untuk itu salah satu upaya pemecahan masalah adalah menggunakan model pembelajaran Picture and picture dengan kelebihan-kelebihan yang mampu memstimulasi rasa ingin tahu peserta didik dan memudahkan pemahamannya dalam belajar.

\section{METODE}

Jenis penelitian ini adalah penelitian tindakan kelas. Penelitian ini dilaksanakan di SDN 98/X Rantau Indah pada semester ganjil, tahun ajaran 2021/2022. Subjek dalam penelitian ini adalah siswa IV dengan jumlah peserta didik 14 orang. Prosedur penelitian ini meliputi perencanaan, pelaksanaan, pengamatan, dan refleksi. Penelitian ini dilaksanakan dalam dua siklus, masing-masing siklus terdiri dari dua kali pertemuan. Teknik yang digunakan dalam pengumpulan data adalah observasi, tes, catatan lapangan dan dokumentasi. Data dianalisis melalui persentase dan reduksi data.

\section{HASIL DAN DISKUSI}

\section{Siklus I}

\section{Perencanaan}

Persiapan yang dilakukan pada perencanaan siklus I adalah mempersiapkan media berupa gambar. Kemudian mempersiapkan RPP (Rencana Pelaksanaan Pembelajaran) siklus I yang bercirikan pembelajaran dengan menggunakan model pembelajaran Kooperatif learning tipe picture and picture. Lalu, Mempersiapkan LKS dan lembar observasi. Setelah itu mempersiapkan format penilaian.

\section{Pelaksanaan}

Pelaksanaan kegiatan belajar mengajar pertemuan pertama untuk siklus I dilaksanakan pada hari Jumat, tanggal 22 Oktober 2021 di Kelas IV SDN 98/X Rantau Indah dengan jumlah peserta didik 14 orang yang membahas subtema tentang Sumber Energi. Dalam hal ini peneliti bertindak sebagai guru. Adapun proses belajar mengajar mengacu pada rencana pelajaran yang telah dipersiapkan. Pertemuan pertama ini diawali dengan kegiatan pendahuluan, kegiatan inti dan kegiatan penutup.

Pada kegiatan pendahuluan ini diawali dengan guru memasuki kelas. Kelas dibuka dengan salam, menanyakan kabar, dan mengecek kehadiran peserta didik. Setelah itu dilanjutkan dengan doa dipimpin oleh salah seorang peserta didik. Peserta didik difasilitasi untuk bertanya jawab pentingnya mengawali setiap kegiatan dengan doa. Selain berdoa, guru dapat memberikan penguatan tentang sikap syukur. Menyanyikan Lagu Indonesia Raya. Guru memberikan penguatan tentang pentingnya menanamkan semangat kebangsaan. Mintalah peserta didik untuk memeriksa kerapian diri dan kebersihan kelas. Peserta didik memperhatikan penjelasan guru tentang tujuan, manfaat, dan aktivitas pembelajaran yang akan dilakukan. Peserta didik menyimak penjelasan guru tentang pentingnya sikap disiplin dan tanggung jawab yang akan dikembangkan dalam pembelajaran. Pembiasaan membaca. 
Peserta didik dan guru mendiskusikan perkembangan kegiatan literasi yang telah dilakukan. Peserta didik ditanya tentang sumber-sumber energi yang ada.

Peserta didik duduk secara berkelompok. Satu kelompok terdiri dari 4 peserta didik. Peserta didik diminta mengamati teks visual yang ada di Buku Peserta didik. Peserta didik menjawab pertanyaan, "Gambar apa saja yang kamu amati?". Setiap kelompok kemudian mendikusikan pertanyaan pada Buku Peserta didik lalu menyampaikan jawabannya kepada kelompok sebelahnya. Peserta didik memperhatikan pembahasan satu persatu gambar di depan kelas. Peserta didik ditunjuk untuk menyampaikan jawabannya. Secara individu, peserta didik akan menuliskan gagasan pokok dari gambar yang telah diamatinya. Peserta didik akan menukar jawabannya kepada teman sebelahnya. Setelah menuliskan gagasan pokok dari gambar, guru mengajak peserta didik mengamati dengan teliti satu jenis tumbuhan. Peserta didik juga diminta untuk mengamati terangnya cuaca di pagi/siang hari dari kaca jendela kelas. Kegiatan mengamati ini sebagai pengantar untuk materi pemanfaatan matahari. Peserta didik menjawab pertanyaan-pertanyaan terkait pengamatan yang baru saja dilakukan. Peserta didik yang mengangkat tangan diminta untuk menjawab pertanyaan yang diajukan. Peserta didik mendiskusikan jawaban-jawaban tersebut bersama guru secara klasikal. Selanjutnya, siwa menerima penguatan tentang matahari sebagai sumber kehidupan di bumi. Setelah itu, peserta didik diminta mengamati gambar tentang peran matahari bagi kehidupan di Bumi. Ingatkan peserta didik untuk mengamati dengan teliti setiap detail pada gambar tersebut. Peserta didik lalu menjawab pertanyaan di buku berdasarkan gambar yang telah diamati. Peserta didik juga diminta untuk mengilustrasikan tentang manfaat lain matahari selain yang tertera pada gambar. Peserta didik kemudian diminta untuk mengubah gambar mereka kedalam bentuk tulisan/cerita. Peserta didik diingatkan kembali tentang manfaat panas matahari, yaitu menguapkan zat cair yang terdapat di Bumi. Pada kegiatan ini, peserta didik digiring untuk dapat berpikir secara luas, dalam, dan kritis untuk dapat memahami hubungan antara matahari dengan kehidupan di bumi. Peserta didik melakukan percobaan untuk membuktikan penguapan zat cair oleh panas matahari, berdasarkan instruksi yang terdapat di buku. (Peserta didik melihat video animasi percobaan penguapan zat cair oleh panas matahari dari Rumah Juara).

Peserta didik melakukan perenungan dengan menjawab pertanyaan yang terdapat dalam Buku Peserta didik halaman. Pertanyaan dari guru berdasarkan panduan yang terdapat pada lampiran pertama Buku. Peserta didik bersama guru menyimpulkan hasil pembelajaran. Peserta didik menyimak penjelasan guru tentang aktivitas pembelajaran pada pertemuan selanjutnya. Termasuk menerima penjelasan tentang kegiatan bersama orangtua, yaitu peserta didik berdiskusi tentang pemanfaatan sumber energi matahari yang terdapat di lingkungan rumah dan sekitarnya. Peserta didik menyimak cerita motivasi tentang pentingnya sikap disiplin dan tanggung jawab. Peserta didik melakukan operasi untuk menjaga kebersihan kelas. Kelas ditutup dengan doa bersama dipimpin salah seorang peserta didik. 
Penggunaan Model Cooperative Learning Tipe Picture and Picture sebagai Upaya Meningkatkan Kreativitas dan Hasil Belajar Muatan IPA Peserta Didik di Kelas IV SDN 98/X Rantau Indah Semester Ganjil Tahun Ajaran 2021/2022, Rosita

Pelaksanaan kegiatan belajar mengajar pertemuan ke dua untuk siklus I dilaksanakan pada hari Jumat, tanggal 29 Oktober 2021 di Kelas IV SDN 98/X Rantau Indah dengan jumlah peserta didik 14 orang yang membahas subtema tentang Sumber Energi. Dalam hal ini peneliti bertindak sebagai guru. Adapun proses belajar mengajar mengacu pada rencana pelajaran yang telah dipersiapkan. Pertemuan pertama ini diawali dengan kegiatan pendahuluan, kegiatan inti dan kegiatan penutup.

Pada kegiatan pendahuluan ini diawali dengan guru memasuki kelas. Kelas dibuka dengan salam, menanyakan kabar, dan mengecek kehadiran peserta didik. Setelah itu dilanjutkan dengan doa dipimpin oleh salah seorang peserta didik. Peserta didik difasilitasi untuk bertanya jawab pentingnya mengawali setiap kegiatan dengan doa. Selain berdoa, guru dapat memberikan penguatan tentang sikap syukur. Menyanyikan Lagu Indonesia Raya. Guru memberikan penguatan tentang pentingnya menanamkan semangat kebangsaan. Mintalah peserta didik untuk memeriksa kerapian diri dan kebersihan kelas. Peserta didik memperhatikan penjelasan guru tentang tujuan, manfaat, dan aktivitas pembelajaran yang akan dilakukan. Peserta didik menyimak penjelasan guru tentang pentingnya sikap disiplin dan tanggung jawab yang akan dikembangkan dalam pembelajaran. Pembiasaan membaca. Peserta didik dan guru mendiskusikan perkembangan kegiatan literasi yang telah dilakukan. Peserta didik ditanya tentang sumber-sumber energi yang ada.

Peserta didik duduk secara berkelompok. Satu kelompok terdiri dari 4 peserta didik. Peserta didik diminta mengamati teks visual yang ada di Buku Peserta didik. Peserta didik menjawab pertanyaan, "Gambar apa saja yang kamu amati?". Setiap kelompok kemudian mendikusikan pertanyaan pada Buku Peserta didik lalu menyampaikan jawabannya kepada kelompok sebelahnya. Peserta didik memperhatikan pembahasan satu persatu gambar di depan kelas. Peserta didik ditunjuk untuk menyampaikan jawabannya. Secara individu, peserta didik akan menuliskan gagasan pokok dari gambar yang telah diamatinya. Peserta didik akan menukar jawabannya kepada teman sebelahnya. Setelah menuliskan gagasan pokok dari gambar, guru mengajak peserta didik mengamati dengan teliti satu jenis tumbuhan. Peserta didik juga diminta untuk mengamati terangnya cuaca di pagi/siang hari dari kaca jendela kelas. Kegiatan mengamati ini sebagai pengantar untuk materi pemanfaatan matahari. Peserta didik menjawab pertanyaan-pertanyaan terkait pengamatan yang baru saja dilakukan. Peserta didik yang mengangkat tangan diminta untuk menjawab pertanyaan yang diajukan. Peserta didik mendiskusikan jawaban-jawaban tersebut bersama guru secara klasikal. Selanjutnya, siwa menerima penguatan tentang matahari sebagai sumber kehidupan di bumi. Setelah itu, peserta didik diminta mengamati gambar tentang peran matahari bagi kehidupan di Bumi. Ingatkan peserta didik untuk mengamati dengan teliti setiap detail pada gambar tersebut. Peserta didik lalu menjawab pertanyaan di buku berdasarkan gambar yang telah diamati. Peserta didik juga diminta untuk mengilustrasikan tentang manfaat lain matahari selain yang tertera pada gambar. Peserta didik kemudian diminta untuk mengubah gambar mereka kedalam bentuk tulisan/cerita. Peserta didik diingatkan kembali tentang manfaat panas matahari, yaitu menguapkan zat cair yang terdapat di 
Bumi. Pada kegiatan ini, peserta didik digiring untuk dapat berpikir secara luas, dalam, dan kritis untuk dapat memahami hubungan antara matahari dengan kehidupan di bumi. Peserta didik melakukan percobaan untuk membuktikan penguapan zat cair oleh panas matahari, berdasarkan instruksi yang terdapat di buku. (Peserta didik melihat video animasi percobaan penguapan zat cair oleh panas matahari dari Rumah Juara).

Peserta didik melakukan perenungan dengan menjawab pertanyaan yang terdapat dalam Buku Peserta didik halaman. Pertanyaan dari guru berdasarkan panduan yang terdapat pada lampiran pertama Buku. Peserta didik bersama guru menyimpulkan hasil pembelajaran. Peserta didik menyimak penjelasan guru tentang aktivitas pembelajaran pada pertemuan selanjutnya. Termasuk menerima penjelasan tentang kegiatan bersama orangtua, yaitu peserta didik berdiskusi tentang pemanfaatan sumber energi matahari yang terdapat di lingkungan rumah dan sekitarnya. Peserta didik menyimak cerita motivasi tentang pentingnya sikap disiplin dan tanggung jawab. Peserta didik melakukan operasi untuk menjaga kebersihan kelas. Kelas ditutup dengan guru menutup pembelajaran dengan mengucapkan salam menutup PBM dan berdo'a bersama.

\section{Observasi}

Pada akhir proses belajar mengajar peserta didik diberi tes formatif I dengan tujuan untuk mengetahui tingkat keberhasilan peserta didik dalam proses belajar mengajar yang telah dilakukan. Adapun data hasil penelitian pada siklus I adalah sebagai berikut: rekapitulasi hasil tes formatif peserta didik seperti terlihat pada tabel berikut.

Tabel 1. Rekapitulasi hasil tes formatif siklus I

\begin{tabular}{|c|c|c|}
\hline No & Uraian & Hasil \\
\hline 1 & Jumlah Nilai & 975 \\
\hline 2 & Rata-rata Nilai & 69.64 \\
\hline 3 & Peserta didik Tuntas & 9 \\
\hline 4 & Peserta didik Tidak Tuntas & 5 \\
\hline 5 & Persentase Peserta didik Tuntas & $64 \%$ \\
\hline 6 & Persentase Peserta didik Tidak Tuntas & $36 \%$ \\
\hline
\end{tabular}

Dari hasil tes formatif di atas dapat dijelaskan bahwa dengan menerapkan model pembelajaran Kooperatif learning tipe picture and picture diperoleh jumlah nilai sebesar 975, nilai rata-rata hasil belajar peserta didik adalah 69,64 dan ketuntasan belajar mencapai $64 \%$ atau ada 9 peserta didik dari 14 peserta didik sudah tuntas belajar. Hasil tersebut menunjukkan bahwa pada siklus pertama secara klasikal peserta didik belum tuntas belajar, karena peserta didik yang memperoleh nilai $\geq 70$ hanya sebesar $64 \%$ lebih kecil dari persentase ketuntasan yang dikehendaki yaitu sebesar $80 \%$. Hal ini disebabkan karena peserta didik masih merasa baru dan belum mengerti apa yang dimaksudkan dan digunakan guru dengan menerapkan model pembelajaran Kooperatif learning tipe picture and picture. 
Penggunaan Model Cooperative Learning Tipe Picture and Picture sebagai Upaya Meningkatkan Kreativitas dan Hasil Belajar Muatan IPA Peserta Didik di Kelas IV SDN 98/X Rantau Indah Semester Ganjil Tahun Ajaran 2021/2022, Rosita

Refleksi

Berikut ini adalah hasil pengamatan oleh kolaborator terhadap proses pembelajaran dengan menggunakan Kooperatif learning tipe picture and picture. Refleksi diadakan di ruang majelis guru pada hari Selasa, tanggal 2 November 2021 yang dibantu oleh seorang observer/kolaborator bernama Elly Siahaan,S.Pd dari hasil pembahasan dengan observer maka, untuk mencapai tujuan yang diharapkan dalam penelitian ini dapat dikemukakan hal-hal sebagai berikut. yaitu masih adanya peserta didik yang masih ngantuk, malu berbicara untuk menegemukakan pendapatnya, dan kurang konsentrasi mengikuti kegiatan pembelajaran sehingga berdampak pada hasil tes formatifnya. Pemecahan masalah untuk siklus berikutnya adalah memberikan reward atau hadiah kepada peserta didik yang berani berbicara dan berargumen untuk mengemukakan pendapatnya. Selain itu reward akan diberikan kepada peserta didik yang mendapat nilai tertinggi. Oleh karena itu penelitian ini dilanjutkan ke siklus ke 2 atau berikutnya.

\section{Siklus II}

\section{Perencanaan}

Berdasarkan hasil refleksi tentang proses dan hasil belajar perlu dilakukan tindakan yang dapat meningkatkan hasil belajar peserta didik. Walaupun hasil belajar peserta didik sudah meningkat pada siklus I, namun masih ada hasil belajar, penilain pemberian pendapat dan rasa puas yang perlu ditingkatkan. Jadi, berdasarkan hal tersebut maka direncanak hal-hal seperti mempersiapkan media berupa gambar. Kemudian mempersiapkan RPP (Rencana Pelaksanaan Pembelajaran) siklus I yang bercirikan pembelajaran dengan menggunakan model pembelajaran Kooperatif learning tipe picture and picture. Mempersiapkan LKS dan lembar observasi. Mempersiapkan format penilaian. Mempersiapkan reward atau hadiah bagi peserta didik yang mendapatkan nilai tertinggi pada hasil tes formatif.

\section{Pelaksanaan}

Pelaksanaan kegiatan belajar mengajar untuk siklus II dilaksanakan pada hari hari Jumat, tanggal 5 November 2021 di Kelas IV dengan jumlah peserta didik 14 orang. Dalam hal ini peneliti bertindak sebagai guru. Adapun proses belajar mengajar mengacu pada rencana pelajaran dengan memperhatikan revisi pada siklus I, sehingga kesalahan atau kekurangan pada siklus I tidak terulang lagi pada siklus II. Pengamatan (observasi) dilaksanakan bersamaan dengan pelaksanaan belajar mengajar. Dan subtema yang dibahas pada pertemuan ini adalah sumber energi.

Pada kegiatan pendahuluan ini diawali dengan guru memasuki kelas. Peserta didik bersama guru menyampaikan salam dan berdoa yang dipimpin oleh ketua kelas. Guru menyapa peserta didik dan mencek kehadiran peserta didik. Peserta didik bersama guru mengondisikan kelas. Guru memberikan motivasi kepada peserta didik untuk mulai belajar. Setelah itu guru menjelaskan tujuan 
hasil belajar dengan menggunakan ungkapan memberi persetujuan. Setelah itu guru mengingatkan kembali peserta didik dan mengaitkan pembelajaran dengan materi sebelumnya.

Peserta didik duduk secara berkelompok. Satu kelompok terdiri dari 4 peserta didik. Peserta didik diminta mengamati teks visual yang ada di Buku Peserta didik. Peserta didik menjawab pertanyaan, "Gambar apa saja yang kamu amati?". Setiap kelompok kemudian mendikusikan pertanyaan pada Buku Peserta didik lalu menyampaikan jawabannya kepada kelompok sebelahnya. Peserta didik memperhatikan pembahasan satu persatu gambar di depan kelas. Peserta didik ditunjuk untuk menyampaikan jawabannya. Secara individu, peserta didik akan menuliskan gagasan pokok dari gambar yang telah diamatinya. Peserta didik akan menukar jawabannya kepada teman sebelahnya. Setelah menuliskan gagasan pokok dari gambar, guru mengajak peserta didik mengamati dengan teliti satu jenis tumbuhan. Peserta didik juga diminta untuk mengamati terangnya cuaca di pagi/siang hari dari kaca jendela kelas. Kegiatan mengamati ini sebagai pengantar untuk materi pemanfaatan matahari. Peserta didik menjawab pertanyaan-pertanyaan terkait pengamatan yang baru saja dilakukan. Peserta didik yang mengangkat tangan diminta untuk menjawab pertanyaan yang diajukan.

Peserta didik mendiskusikan jawaban-jawaban tersebut bersama guru secara klasikal. Selanjutnya, siwa menerima penguatan tentang matahari sebagai sumber kehidupan di bumi. Setelah itu, peserta didik diminta mengamati gambar tentang peran matahari bagi kehidupan di Bumi. Ingatkan peserta didik untuk mengamati dengan teliti setiap detail pada gambar tersebut. Peserta didik lalu menjawab pertanyaan di buku berdasarkan gambar yang telah diamati. Peserta didik juga diminta untuk mengilustrasikan tentang manfaat lain matahari selain yang tertera pada gambar. Peserta didik kemudian diminta untuk mengubah gambar mereka kedalam bentuk tulisan/cerita. Peserta didik diingatkan kembali tentang manfaat panas matahari, yaitu menguapkan zat cair yang terdapat di Bumi. Pada kegiatan ini, peserta didik digiring untuk dapat berpikir secara luas, dalam, dan kritis untuk dapat memahami hubungan antara matahari dengan kehidupan di bumi. Peserta didik melakukan percobaan untuk membuktikan penguapan zat cair oleh panas matahari, berdasarkan instruksi yang terdapat di buku. (Peserta didik melihat video animasi percobaan penguapan zat cair oleh panas matahari dari Rumah Juara).

Pada kegiatan penutup ini, guru memberikan reward atau hadiah bagi peserta didik yang telah berani berbicara dan berargumen mengenai materi pembelajaran yang telah dibahas pada pertemuan ke dua siklus II ini. Kemudian Peserta didik melakukan perenungan dengan menjawab pertanyaan yang terdapat dalam Buku Peserta didik. Pertanyaan dari guru berdasarkan panduan yang terdapat pada lampiran pertama Buku. Peserta didik bersama guru menyimpulkan hasil pembelajaran. Peserta didik menyimak penjelasan guru tentang aktivitas pembelajaran pada pertemuan selanjutnya. Termasuk menerima penjelasan tentang kegiatan bersama orangtua, yaitu peserta didik berdiskusi tentang pemanfaatan sumber energi matahari yang terdapat di lingkungan rumah dan sekitarnya. Peserta didik menyimak cerita motivasi tentang pentingnya sikap disiplin dan tanggung jawab. Peserta 
Penggunaan Model Cooperative Learning Tipe Picture and Picture sebagai Upaya Meningkatkan Kreativitas dan Hasil Belajar Muatan IPA Peserta Didik di Kelas IV SDN 98/X Rantau Indah Semester Ganjil Tahun Ajaran 2021/2022, Rosita

didik melakukan operasi untuk menjaga kebersihan kelas. Kelas ditutup dengan guru menutup pembelajaran dengan mengucapkan salam menutup PBM dan ber do'a bersama.

Pelaksanaan kegiatan belajar mengajar pertemuan ke dua untuk siklus II dilaksanakan pada hari Jumat, tanggal 19 November 2021 dengan jumlah peserta didik sebanyak 14 orang yang membahas subtema sumber energi. Dalam hal ini peneliti bertindak sebagai guru. Adapun proses belajar mengajar mengacu pada rencana pelajaran yang telah dipersiapkan. Pertemuan pertama ini diawali dengan kegiatan pendahuluan, kegiatan inti dan kegiatan akhir.

Kelas dibuka dengan salam, menanyakan kabar, dan mengecek kehadiran peserta didik. Kemudian kelas dilanjutkan dengan doa dipimpin oleh salah seorang peserta didik. Peserta didik difasilitasi untuk bertanya jawab pentingnya mengawali setiap kegiatan dengan doa. Selain berdoa, guru dapat memberikan penguatan tentang sikap syukur. Lalu peserta didik diajak menyanyikan Lagu Indonesia Raya. Guru memberikan penguatan tentang pentingnya menanamkan semangat kebangsaan. Peserta didik diminta untuk memeriksa kerapian diri dan kebersihan kelas. Peserta didik memperhatikan penjelasan guru tentang tujuan, manfaat, dan aktivitas pembelajaran yang akan dilakukan. Peserta didik menyimak penjelasan guru tentang pentingnya sikap disiplin dan tanggung jawab yang akan dikembangkan dalam pembelajaran. Lalu Pembiasaan membaca. Peserta didik dan guru mendiskusikan perkembangan kegiatan literasi yang telah dilakukan. Peserta didik menjawab pertanyaan tentang cara membuat kincir berputar kencang.

Pada kegiatan inti ini guru Peserta didik mengamati secara saksama gambar kincir angin. Peserta didik menyajikan dan mengomunikasikan hasil pengamatannya secara tertulis. Peserta didik mengamati rangkaian gambar untuk kemudian menyusun menjadi sebuah cerita. Peserta didik menyimak penjelasan guru tentang kincir angin. Peserta didik menemukan sebanyak mungkin cara untuk membuat kincir berputar kencang. Peserta didik menjawab pertanyaan-pertanyaan pancingan untuk membangun kemampuan berpikir kritis. Peserta didik dimotivasi untuk berpikir secara luas dan dalam. Peserta didik lalu diminta membaca teks singkat tentang kegiatan yang akan mereka lakukan. Peserta didik akan membuat kincir berdasarkan instruksi di buku. Namun sebelumnya, peserta didik disarankan mengamati teks visual dan intruksi yang ada di Buku Peserta didik. Pada kegiatan ini, peserta didik dimotivasi untuk membaca dengan cermat teks yang ada. Kemudian, peserta didik saling menceritakan isi teks kepada temannya. Peserta didik yang masih kesulitan memahami gagasan dari teks yang dibacanya dicatat oleh guru sebagai petunjuk untuk melakukan kegiatan remedial. Selanjutnya, peserta didik membaca dengan teliti panduan keselamatan kerja sebelum mulai membuat kincir. Peserta didik kemudian membuat kincir berdasarkan instruksi yang terdapat di buku, dengan batasan waktu yang ditentukan guru.

Pada kegiatan ini, guru berkeliling memastikan peserta didik mengerjakan tugas dengan tertib dan mematuhi panduan keselamatan kerja. Setelah kincir selesai, ingatkan peserta didik untuk bersama-sama merapikan alat-alat serta sisa-sisa bahan. Peserta didik melakukan percobaan menggunakan air mengalir untuk kincir plastik dan menggunakan tiupan angin untuk kincir kertas. 
Setelah melakukan percobaan, peserta didik mendiskusikan perbedaan kecepatan putaran balingbaling pada kedua jenis kincir tersebut. Peserta didik juga diharapkan menemukan perbedaanperbedaan lainnya. Peserta didik kemudian menuliskan perbedaan tersebut dalam diagram yang tersedia. Peserta didik dapat memasang kincir-kincir mereka di sekitar sekolah pada tempat dan ketinggian yang berbeda. Peserta didik kemudian dapat mengobservasi dan mengidentifikasi faktorfaktor yang mengakibatkan kincir mereka dapat berputar kencang atau sebaliknya. Peserta didik menuliskan laporan hasil percobaan pada bagan yang tersedia. Peserta didik diingatkan untuk menganalisis hasil percobaan dengan teliti, dengan memperhitungkan faktor-faktor pendukung yang menyebabkan kincir berada pada kondisi tertentu. Peserta didik dalam kelompok yang sama mendiskusikan pertanyaan-pertanyaan yang terdapat di buku berdasarkan hasil percobaan. Peserta didik menuliskan jawaban pertanyaan-pertanyaan tersebut di buku. Peserta didik menerima penguatan mengenai sumber energi angin. (Peserta didik melihat animasi manfaat kincir dalam kehidupan sehari-hari dari Rumah Juara).

Pada kegiatan penutup ini, guru memberikan reward atau hadiah bagi peserta didik yang telah berani berbicara dan berargumen mengenai materi pembelajaran yang telah dibahas pada pertemuan ke dua siklus II, dan bagi peserta didik yang mendapat nilai tertinggi, setelah itu Guru memberikan tes. Guru mengumpulkan hasil tes. Peserta didik melakukan perenungan dengan menjawab pertanyaan yang terdapat dalam Buku Peserta didik. Peserta didik bersama guru menyimpulkan hasil pembelajaran. Peserta didik menyimak penjelasan guru tentang aktivitas pembelajaran pada pertemuan selanjutnya. Termasuk menerima penjelasan tentang kegiatan bersama orangtua, yaitu peserta didik membuat kincir angin baru bersama orang tua di rumah dengan menggunakan berbagai macam kertas, seperti kertas koran, majalah, atau kertas kado. Kemudian, peserta didik dapat memasang kincir mereka di halaman rumah. Peserta didik menyimak cerita motivasi tentang pentingnya sikap disiplin dan tanggung jawab. Peserta didik melakukan operasi untuk menjaga kebersihan kelas. Kelas ditutup dengan doa bersama dipimpin salah seorang peserta didik.

\section{Observasi}

Pada akhir proses belajar mengajar peserta didik diberi tes formatif II dengan tujuan untuk mengetahui tingkat keberhasilan peserta didik selama proses belajar mengajar yang telah dilakukan. Instrumen yang digunakan adalah tes. Adapun data hasil penelitian pada siklus II adalah sebagai berikut. Berikut ini adalah rekapitulasi hasil tes formatif peserta didik terlihat pada tabel berikut.

Tabel 2. Rekapitulasi hasil tes formatif siklus II

\begin{tabular}{|c|c|c|}
\hline No & Uraian & Hasil \\
\hline 1 & Jumlah Nilai & 1035 \\
\hline 2 & Rata-rata Nilai & 73.93 \\
\hline 3 & Peserta didik Tuntas & 12 \\
\hline 4 & Peserta didik Tidak Tuntas & 2 \\
\hline 5 & Persentase Peserta didik Tuntas & $86 \%$ \\
\hline
\end{tabular}


Penggunaan Model Cooperative Learning Tipe Picture and Picture sebagai Upaya Meningkatkan Kreativitas dan Hasil Belajar Muatan IPA Peserta Didik di Kelas IV SDN 98/X Rantau Indah Semester Ganjil Tahun Ajaran 2021/2022, Rosita

Dari hasil tes formatif di atas diperoleh jumlah nilai peserta didik sebesar 1035 dengan ratarata hasil belajar peserta didik adalah 73,93 dan ketuntasan belajar mencapai 86\%, dimana 12 dari 14 peserta didik sudah tuntas belajar. Hasil ini menunjukkan bahwa pada siklus II ini ketuntasan belajar secara klasikal telah mengalami peningkatan sangat baik dari siklus I. Adanya peningkatan hasil belajar peserta didik ini karena setelah guru menginformasikan bahwa pada saat pembelajaran akan diberikan reward atau hadiah bagi peserta didik yang aktif bertanya dan bagi yang mendapatkan nilai tertinggi. Kemudian setiap akhir pelajaran akan selalu diadakan tes sehingga pada pertemuan berikutnya peserta didik lebih termotivasi untuk belajar. Selain itu peserta didik juga sudah mulai mengerti apa yang dimaksudkan dan dinginkan guru dengan menerapkan model pembelajaran Kooperatif learning tipe picture and picture.

\section{Refleksi}

Berikut ini adalah hasil pengamatan oleh kolaborator terhadap proses pembelajaran dengan menggunakan model Kooperatif learning tipe picture and picture pada Siklus II dari pertemuan 1 pada hari Selasa, tanggal 23 November 2021 yang dibantu oleh seorang observer/kolaborator bernama Elly Siahaan,S.Pd Maka untuk mencapai tujuan yang diharapkan dalam penelitian ini dapat dikemukakan hal-hal sebagai berikut, peserta didik sudah bersemangat dalam mengikuti proses PBM, hal ini terbukti dengan beraninya peserta didik untuk berbicara dan menyampaikan argumennya di kelas dan menanyakan hal-hal yang tidak dimengerti. Kemudian faktor reward atau hadiah juga berpengaruh terhadap peningkatan hasil belajar peserta didik. Selain itu juga dapat dilihat dari nilai yang dicapai $86 \%$ tuntas. Untuk itu penelitian tidak dilanjutkan ke siklus III atau ke siklus berikutnya.

\section{Diskusi}

Melalui hasil peneilitian ini menunjukkan bahwa model pembelajaran Kooperatif learning tipe picture and picture memiliki dampak positif dalam meningkatkan hasil belajar peserta didik. Hal ini dapat dilihat dari semakin mantapnya pemahaman peserta didik terhadap materi yang disampaikan guru (ketuntasan belajar meningkat dari siklus I, dan II yaitu masing-masing 64\%, dan 86\%. Pada siklus II ketuntasan belajar peserta didik secara klasikal telah tercapai dan dengan adanya tindakan pemberian reward atau hadiah. Hal ini sesuai dengan pendapat Sudjana (2004) bahwa hasil belajar peserta didik pada hakikatnya adalah perubahan tingkah laku sebagai hasil belajar dalam pengertian yang lebih luas mencakup bidang kognitif, afektif, dan psikomotorik. Untuk lebih jelasnya dapat dilihat pada gambar di bawah ini. 


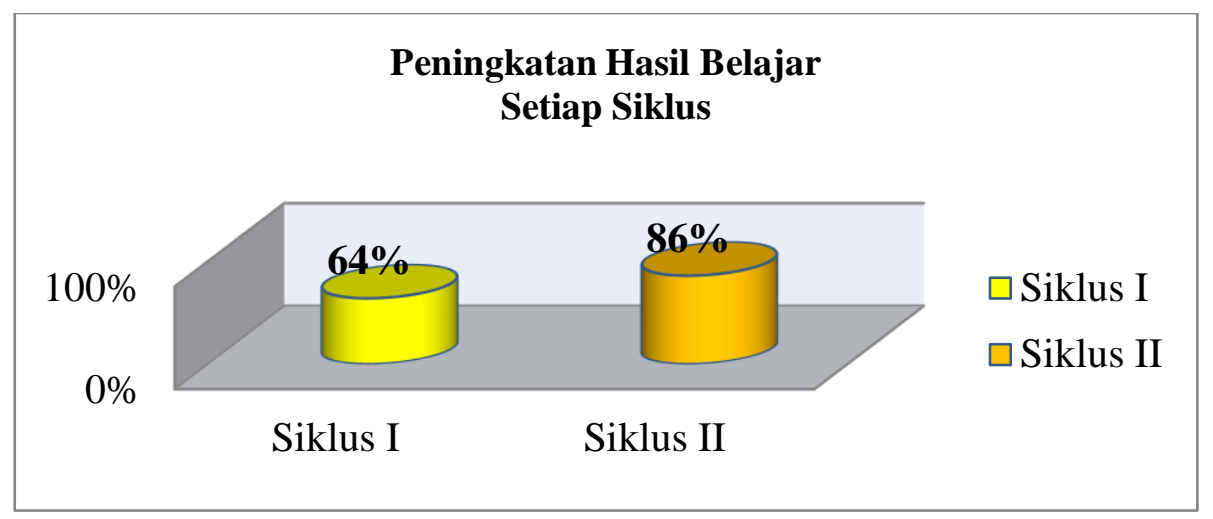

Gambar 1. Grafik Peningkatan Hasil Belajar Setiap Siklus

\section{KESIMPULAN}

Dari hasil kegiatan pembelajaran yang telah dilakukan selama dua siklus, dan berdasarkan seluruh pembahasan serta analisis yang telah dilakukan dapat disimpulkan bahwasanya pembelajaran dengan model pembelajaran Kooperatif learning tipe picture and picture memiliki dampak positif dalam meningkatkan kreativitas dan hasil belajar muatan IPA peserta didik di kelas IV SDN 98/X Rantau Indah yang ditandai dengan peningkatan ketuntasan belajar peserta didik dalam setiap siklus, yaitu siklus I (64\%) dan siklus II (86\%) dan dengan adanya tindakan pemberian reward atau hadiah.

Dari hasil penelitian yang diperoleh dari uraian sebelumnya agar proses belajar pembelajaran tematik lebih efektif dan lebih memberikan hasil yang optimal bagi peserta didik, maka disampaikan saran yaitu dalam rangka meningkatkan prestasi belajar peserta didik, guru hendaknya lebih sering melatih peserta didik dengan berbagai model pengajaran, walau dalam taraf yang sederhana, dimana peserta didik nantinya dapat menemukan pengetahuan baru, memperoleh konsep dan keterampilan, sehingga peserta didik berhasil atau mampu memecahkan masalah-masalah yang dihadapinya. Untuk melaksanakan model pembelajaran Kooperatif learning tipe picture and picture memerlukan persiapan yang cukup matang, sehingga guru harus mampu menentukan atau memilih topik yang benar-benar bisa diterapkan dengan model pembelajaran Kooperatif learning tipe picture and picture dalam proses belajar mengajar sehingga diperoleh hasil yang optimal. Untuk penelitian yang serupa hendaknya dilakukan perbaikan-perbaikan agar diperoleh hasil yang lebih baik. Kemudian Perlu adanya penelitian yang lebih lanjut, karena hasil penelitian ini hanya dilakukan di kelas IV SDN 98/X Rantau Indah semester ganjil Tahun Ajaran 2021/2022.

\section{REFERENSI}

Abdullah Aly, Eny Rahma. 2009. Ilmu Alamiah Dasar.Jakarta:PT Bumi Kasara

Ali Mudlofir, Evi Fitamatur Rusyidah, Ismet Basuki, Hariyanto. 2014. Asesmen Pembelajaran. Bandung:PT Remaja Rosdakarya

Miftahhul Huda. 2013. Model Model Pengajaran dan Pembelajaran. Yogyakarta: Pustaka Pelajar. 
Penggunaan Model Cooperative Learning Tipe Picture and Picture sebagai Upaya Meningkatkan Kreativitas dan Hasil Belajar Muatan IPA Peserta Didik di Kelas IV SDN 98/X Rantau Indah Semester Ganjil Tahun Ajaran 2021/2022, Rosita

Muh, Yusuf Mappease. 2009. Pengaruh Cara Dan Motivasi Belajar Hasil Belajar Programmabel Logic Controller (PLC) Peserta didik Kelas III Jurusan Listrik SMK Negeri 5 Makasar.Vol 1, No 2 Jurnal MEDTEK.Teknik UNM.

Ngalimun. 2013. Strategi dan Model Pembelajaran. Jakarta: Aswaja Persido

Ni Komang Sri Marini, dkk.2009.Penerapan Model Model Pembelajaran Picture Pictur Melalui Media Gambar Untuk Meningkatkan Keterampilan Berbicara Pada Anak Taman Kanak Kanak.Jurnal Universitas Ganesha Singraja.

Rivo Panji Yudha.2018.Perbandingan Hasil Belajar Matemateka Peserta didik antara Model Pembelajaran Tari Bambu Dengan Model Pembelajaran Two Stay Two Stray.EduMa Vol. 7 No. 1 Juli 2018 ISSN 2086-3918.FKIP Universitas.

Rusman. 2009.Model Model Pembelajaran. Depok: Raja Grafindo Persada

Sudjana, Nana. 2004. Dasar-dasar Proses Belajar Mengajar. Bandung: Sinar Baru Algensido Offset

Sulihin Bsjukur.2012. Pengaruh Blended Learning Terhadap Motivasi Belajar dan Hasil Belajar tingkat SMK.Vol2, No 3 Jurnal Pendidikan Vokasi. 